2004

\title{
Dinitrogen Fixation and Release of Ammonium and Dissolved Organic Nitrogen by Trichodesmium IMS101
}

Margaret R. Mulholland

Old Dominion University, mmulholl@odu.edu

Deborah A. Bronk

Douglas G. Capone

Follow this and additional works at: https://digitalcommons.odu.edu/oeas_fac_pubs

Part of the Ecology and Evolutionary Biology Commons, Marine Biology Commons, Microbiology Commons, and the Oceanography Commons

\section{Repository Citation}

Mulholland, Margaret R.; Bronk, Deborah A.; and Capone, Douglas G., "Dinitrogen Fixation and Release of Ammonium and Dissolved Organic Nitrogen by Trichodesmium IMS101" (2004). OEAS Faculty Publications. 305.

https://digitalcommons.odu.edu/oeas_fac_pubs/305

\section{Original Publication Citation}

Mulholland, M. R., Bronk, D. A., \& Capone, D. G. (2004). Dinitrogen fixation and release of ammonium and dissolved organic nitrogen by Trichodesmium IMS101. Aquatic Microbial Ecology, 37(1), 85-94. doi:10.3354/ame037085 


\title{
Dinitrogen fixation and release of ammonium and dissolved organic nitrogen by Trichodesmium IMS101
}

\author{
Margaret R. Mulholland ${ }^{1, *}$, Deborah A. Bronk ${ }^{2}$, Douglas G. Capone ${ }^{3}$ \\ ${ }^{1}$ Department of Ocean, Earth and Atmospheric Sciences, Old Dominion University, 4600 Elkhorn Avenue, Norfolk, \\ Virginia 23529-0276, USA \\ ${ }^{2}$ Department of Physical Science, Virginia Institute of Marine Science, The College of William and Mary, Greate Rd., \\ Gloucester Point, Virginia 23062, USA \\ ${ }^{3}$ Wrigley Institute of Environmental Studies and Department of Biological Sciences, University of Southern California, \\ Los Angeles, California 90089, USA
}

\begin{abstract}
Two methods used to measure dinitrogen $\left(\mathrm{N}_{2}\right)$ fixation (acetylene reduction and ${ }^{15} \mathrm{~N}_{2}$ uptake) often result in different $\mathrm{N}_{2}$ fixation rates. Part of the discrepancy may arise from the observation that Trichodesmium can release a fraction of their recently fixed $\mathrm{N}_{2}$ as dissolved organic nitrogen (DON) and/or ammonium $\left(\mathrm{NH}_{4}{ }^{+}\right)$. To resolve outstanding issues regarding $\mathrm{N}_{2}$ fixation and the production of dissolved combined nitrogen $(\mathrm{N})$ by Trichodesmium, we conducted a comprehensive analysis of $\mathrm{N}_{2}$ fixation and the production of DON and $\mathrm{NH}_{4}{ }^{+}$in cultures of Trichodesmium IMS101. We performed ${ }^{15} \mathrm{~N}_{2}$ uptake experiments in parallel with acetylene $\left(\mathrm{C}_{2} \mathrm{H}_{2}\right)$ reduction assays, and measured production of ${ }^{15} \mathrm{NH}_{4}{ }^{+}$and $\mathrm{DO}^{15} \mathrm{~N}$ from ${ }^{15} \mathrm{~N}_{2}$, and ${ }^{15} \mathrm{NH}_{4}{ }^{+}$uptake and regeneration by isotope dilution. Four main results are highlighted. First, ${ }^{15} \mathrm{~N}_{2}$ uptake appears to provide a better approximation of net $\mathrm{N}$-specific growth rates than $\mathrm{N}_{2}$ fixation estimates made using $\mathrm{C}_{2} \mathrm{H}_{2}$ reduction. Second, the $\mathrm{C}_{2} \mathrm{H}_{2}$ reduction method provides a closer approximation of gross $\mathrm{N}_{2}$ fixation. Third, simultaneous measurements of relevant $\mathrm{N}$ pools and pathways by several methods enabled us to rigorously evaluate deviations from theoretical conversion factors and to interpret the basis for those deviations. Our results suggest that a conversion ratio (mol $\mathrm{C}_{2} \mathrm{H}_{2}$ reduced: mol $\mathrm{N}_{2}$ reduced to PON, ammonium and DON) of 4:1 may be more appropriate for total $\mathrm{N}_{2}$ fixation. Fourth, the difference between estimates of gross $\mathrm{N}_{2}$ fixation, made using the $\mathrm{C}_{2} \mathrm{H}_{2}$ reduction technique, and net ${ }^{15} \mathrm{~N}_{2}$ uptake into particulate $\mathrm{N}$ may be a good indicator of $\mathrm{N}$ release from $\mathrm{N}_{2}$ fixation.
\end{abstract}

KEY WORDS: Nitrogen fixation · Nitrogen regeneration · Trichodesmium • Ammonium uptake · Ammonium regeneration

\section{INTRODUCTION}

Trichodesmium spp. fix dinitrogen $\left(\mathrm{N}_{2}\right)$, and thereby introduce new nitrogen $(\mathrm{N})$ in regions where they occur. While this capability precludes $\mathrm{N}$ limitation of Trichodesmium growth and biomass accumulation, it is unclear how inputs of new $\mathrm{N}$ from $\mathrm{N}_{2}$ fixation affect nutrient cycling and productivity in the oligotrophic ocean in general. It has been reported that Trichodesmium spp. release upwards of $50 \%$ of recently fixed $\mathrm{N}_{2}$ as dissolved organic $\mathrm{N}$ (DON) (Glibert \& Bronk 1994); largely, it appears, as amino acids (Capone et al. 1994). In natural systems, this recently fixed $\mathrm{N}$ may provide combined $\mathrm{N}$ to support production by associated auto- and heterotrophs.

In culture systems, ammonium $\left(\mathrm{NH}_{4}{ }^{+}\right)$appears to be the primary recycling intermediate for recently fixed $\mathrm{N}_{2}$ (Mulholland \& Capone 2001). While $\mathrm{N}_{2}$ fixation accounted for the net production of new biomass, release and uptake of $\mathrm{NH}_{4}{ }^{+}$fueled additional and rapid 
turnover of this pool. Previous research demonstrated that both dissolved free amino acids (DFAA) and $\mathrm{NH}_{4}{ }^{+}$ accumulate in the culture medium during growth (Mulholland et al. 1999, Mulholland \& Capone 2001), but only $\mathrm{NH}_{4}{ }^{+}$is simultaneously taken up under these conditions (see also Mulholland \& Capone 1999). Subsequent results from kinetic experiments that examined $\mathrm{NH}_{4}{ }^{+}$uptake using incubation times of various lengths diverged widely; Trichodesmium showed a high affinity for $\mathrm{NH}_{4}{ }^{+}$, but the longer the incubation time, the lower the apparent maximum specific uptake rate $\left(V_{\max }\right)$ (Mulholland et al. 1999; our Fig. 1). These results suggest that for $\mathrm{NH}_{4}{ }^{+}$, isotope dilution could be substantial (e.g. King \& Berman 1984).

Though these earlier results indicated the potential importance of rapid $\mathrm{NH}_{4}{ }^{+}$release and uptake by Trichodesmium, not all relevant pools and processes were measured, e.g. direct release of $\mathrm{DON}$ and $\mathrm{NH}_{4}{ }^{+}$. The objective of this study was to obtain a more comprehensive picture of the fate of recently fixed $\mathrm{N}_{2}$. To accomplish this, another series of culture experiments were conducted in which we directly measured $\mathrm{NH}_{4}{ }^{+}$ uptake as well as the production of dissolved $\mathrm{NH}_{4}{ }^{+}$and DON from recently fixed $\mathrm{N}_{2}$ and $\mathrm{NH}_{4}{ }^{+}$regeneration by isotope dilution.

While culture systems do not mimic the complexity of population interactions observed in nature, we chose them as an effective tool to better understand and complement field estimates and to identify and isolate relevant pathways affecting the cycling of nutrients under defined physiological conditions. In nature, the prior physiological history and status of freshly collected Trichodesmium colonies or cells is generally unknown and biomass constraints often prevent the simultaneous measurement of relevant $\mathrm{N}$ cycling pathways.

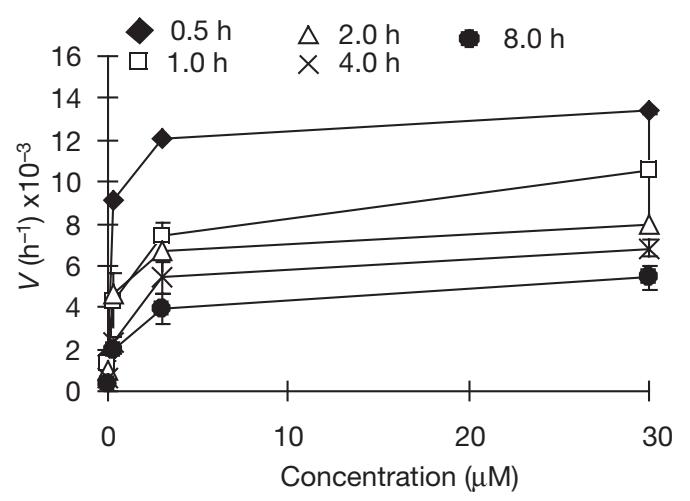

Fig. 1. Saturation kinetics for $\mathrm{NH}_{4}{ }^{+}$uptake in Trichodesmium NIBB1067 grown on medium without added $\mathrm{N}$ substrates during $0.5,1.0,2.0,4.0$ and $8.0 \mathrm{~h}$ incubations. Error bars represent the standard deviations from replicate uptake measurements. $V$ : specific uptake rate

\section{MATERIALS AND METHODS}

Rates of $\mathrm{N}_{2}$ fixation were measured by 2 methods: (1) using ${ }^{15} \mathrm{~N}$-labeled $\mathrm{N}_{2}$, which estimates net $\mathrm{N}$ accumulation into particulate organic nitrogen (PON); and (2) using the acetylene $\left(\mathrm{C}_{2} \mathrm{H}_{2}\right)$ reduction method, which estimates total $\mathrm{N}_{2}$ fixation. Likewise, $\mathrm{NH}_{4}{ }^{+}$ regeneration was measured in 2 ways: (1) by adding ${ }^{15} \mathrm{~N}$-labeled $\mathrm{N}_{2}$ gas and quantifying the appearance of ${ }^{15} \mathrm{~N}$ in the $\mathrm{NH}_{4}{ }^{+}$pool; and (2) by adding ${ }^{15} \mathrm{~N}$-labeled $\mathrm{NH}_{4}{ }^{+}$and measuring the degree of isotope dilution over time (Glibert et al. 1982). DON was also isolated at the end of the ${ }^{15} \mathrm{~N}_{2}$ incubations so that rates of DON release could be measured directly. These measurements were made periodically over an entire growth cycle to quantify the effect of the population's changing physiological state.

Batch cultures of Trichodesmium IMS101 were grown on an artificial seawater medium without added $\mathrm{N}$ (Chen et al. 1996). While cultures were not entirely free of contaminating bacteria, their numbers were kept low by maintaining cultures in exponential phase growth and performing transfers using sterile techniques. Cultures were grown at $27^{\circ} \mathrm{C}$ on a $12: 12 \mathrm{~h}$ light:dark cycle under cool, white fluorescent lighting, supplied at between 55 and $65 \mu \mathrm{mol}$ quanta $\mathrm{m}^{-2} \mathrm{~s}^{-1}$ PAR. Cells were routinely mixed to prevent their adhesion to the sides of the culture vessels.

Experiments were initiated by inoculating 34 replicate culture vessels containing $\mathrm{N}$-free medium with equal volumes of an exponentially growing Trichodesmium parent culture. Trichodesmium filament counts, PON and chlorophyll a ( $\mathrm{chl}$ a) biomass were used to establish growth rates of the culture during the $18 \mathrm{~d}$ experiment. At each sampling point (about every 2 d), samples were preserved with Lugol's solution and the number of filaments (or trichomes) enumerated microscopically. Concentrations of PON were measured on an ANCA GSL interfaced with a Europa GEO 20/20 isotope ratio mass spectrometer (IRMS) at the end of ${ }^{15} \mathrm{~N}$ experiments. Another set of samples were filtered onto pre-combusted $\left(450^{\circ} \mathrm{C}\right.$ for $2 \mathrm{~h}$ ) GF/F filters and frozen for chl a analysis (spectrophotometric determination after extraction in methanol; Mackinney 1941); the filtrates were frozen for analysis of $\mathrm{NH}_{4}{ }^{+}$ concentrations (autoanalyzer; Friederich \& Whitledge 1972), DFAA (high performance liquid chromatography [HPLC]; Cowie \& Hedges 1992) and total dissolved nitrogen (TDN) (persulfate oxidation; Bronk et al. 2000). DON was calculated as the difference between TDN and $\mathrm{NH}_{4}{ }^{+}$. Instrument error based on repeat injection was less than $10 \%$ for $\mathrm{NH}_{4}{ }^{+}$and DFAA analyses. Nitrate concentrations were always undetectable in previous culture experiments using media without added $\mathrm{N}$, and so it was not measured during this study. 
Prufert-Bebout et al. (1993) observed nitrate concentrations of about $0.5 \mu \mathrm{M}$ in cultures; however, these were grown on seawater-based media rather than the defined medium used for this study.

At each time point, samples for intracellular pools of $\mathrm{NH}_{4}{ }^{+}$and DFAA were also collected. For these measurements, an aliquot of culture was filtered through a $3.0 \mu \mathrm{m}$ filter and the retained Trichodesmium filaments and filters were rinsed with fresh medium. The filter tower was then placed onto an acid-cleaned filter flask and $25 \mathrm{ml}$ of boiling deionized and distilled water was added to the filter tower (combined heat and osmotic shock; see Thoresen et al. 1982). The resulting filtrate was collected and frozen for analysis of dissolved $\mathrm{NH}_{4}{ }^{+}$ and DFAA using the methods described above.

Over the course of the $18 \mathrm{~d}$ experiment, replicate cultures were sacrificed for rate measurements. All measurements were made simultaneously at mid-day because rates of $\mathrm{N}_{2}$ fixation are restricted to the light cycle and are maximal at or near mid-day. Rates of $\mathrm{N}_{2}$ fixation, $\mathrm{NH}_{4}{ }^{+}$uptake, and ${ }^{15} \mathrm{NH}_{4}{ }^{+}$and $\mathrm{DO}^{15} \mathrm{~N}$ production from ${ }^{15} \mathrm{~N}_{2}$ were measured using highly enriched (96 to $99 \%$ ) ${ }^{15} \mathrm{~N}_{2}$ and ${ }^{15} \mathrm{NH}_{4}{ }^{+}$substrates as described below (Mulholland et al. 1999, Mulholland \& Capone 2001). A previous study indicated that Trichodesmium might have significant intracellular pools of $\mathrm{NH}_{4}{ }^{+}$and DFAA (Mulholland et al. 1999). If this is the case, then $\mathrm{NH}_{4}{ }^{+}$and DON production from ${ }^{15} \mathrm{~N}_{2}$ might be underestimated. So, in addition, independent estimates of ${ }^{15} \mathrm{NH}_{4}{ }^{+}$uptake and regeneration were made using the isotope dilution technique (Glibert et al. 1982). Because of culture volume constraints, isotope dilution experiments were not replicated.

Rates of $\mathrm{N}_{2}$ and $\mathrm{NH}_{4}{ }^{+}$uptake were measured using tracer additions $(<10 \%)$ of highly enriched $(99 \%){ }^{15} \mathrm{~N}_{2}$ and ${ }^{15} \mathrm{NH}_{4}{ }^{+}$(Montoya et al. 1996, Mulholland \& Capone 1999, 2001, Mulholland et al. 1999). For ${ }^{15} \mathrm{~N}_{2}$ uptake experiments, combusted $\left(450^{\circ} \mathrm{C}\right.$ overnight) Pyrex bottles ( $159 \mathrm{ml}$ total volume) were filled to overflowing before being sealed with a septum cap (Teflonlined butyl rubber). A gas-tight syringe was used to inject $160 \mu \mathrm{l}$ of ${ }^{15} \mathrm{~N}_{2}$ (Cambridge Isotopes Laboratories) into each incubation bottle as described by Montoya et al. (1996). Sample bottles were then replaced in the incubator. Ambient $\mathrm{N}_{2}$ concentrations in the culture bottles were calculated using the equations of Weiss (1970), assuming that cultures were at equilibrium with the atmosphere at the start of incubations. The resulting ${ }^{15} \mathrm{~N}_{2}$ additions were about $10 \% .{ }^{15} \mathrm{NH}_{4}{ }^{+}$ uptake experiments were done in combusted $25 \mathrm{ml}$ glass scintillation vials. Twenty $\mathrm{ml}$ of culture was placed in each vial and $0.03 \mu \mathrm{M}{ }^{15} \mathrm{NH}_{4}{ }^{+}(<10 \%$ of the ambient pool) was added to initiate incubations.

An advantage of measuring $\mathrm{N}_{2}$ fixation using ${ }^{15} \mathrm{~N}_{2}$ is that dissolved $\mathrm{NH}_{4}{ }^{+}$and DON pools can be isolated and the production of dissolved ${ }^{15} \mathrm{NH}_{4}{ }^{+}$and $\mathrm{DO}^{15} \mathrm{~N}$ can be measured in the sample filtrate from uptake experiments. The DON pool was isolated using ion retardation resin (Bronk \& Glibert 1993, Bronk et al. 1998). The manufacturing process of the resin formally used in this isolation, BioRad AG 11 A8 (Bronk \& Glibert 1991), changed in the early 1990s. As a result of the change, the resin now retains a variable amount of DON (Bronk 2002). The resin used in this study was manufactured in the Bronk lab by chemically altering another resin (Dowex anion exchange resin, BioRad AG1-X8) to produce AG 11 A8 using the method of Hatch et al. (1957). The resin produced in the lab did not retain DON, but had an isolation efficiency comparable to the original BioRad AG 11 A8 resin as described in Bronk \& Glibert (1991). The $\mathrm{NH}_{4}{ }^{+}$pool was isolated with solid phase extraction (Dudek et al. 1986). The recovery from solid phase extraction was, on average, $35 \%$. The low recovery is a result of the inefficiency in transferring the column eluate to a glass fiber filter prior to mass spectrometric analysis. Because the loss of sample does not result from a chemical reaction, there is no discernible isotopic fractionation. As in previous studies, rates of ${ }^{15} \mathrm{NH}_{4}{ }^{+}$and $\mathrm{DO}^{15} \mathrm{~N}$ production from ${ }^{15} \mathrm{~N}_{2}$ were calculated using $\mathrm{N}_{2}$ as the source pool (Eq. 1; Glibert \& Bronk 1994). This assumes that intracellular pools of $\mathrm{NH}_{4}{ }^{+}$and DON are minimal and that release of these compounds occurs prior to their assimilation into particulate $\mathrm{N}$.

$$
\begin{aligned}
\underset{\mathrm{NH}_{4}^{+} \text {or DON }}{\text { production }}= & \frac{\text { atom } \% \text { excess } \mathrm{NH}_{4}^{+} \text {or DON }}{\text { atom } \% \text { enrichment } \mathrm{N}_{2} \times \text { incubation time }} \\
& \times\left[\mathrm{NH}_{4}^{+}\right] \text {or }[\mathrm{DON}]
\end{aligned}
$$

Uptake of ${ }^{15} \mathrm{~N}_{2}$ and production of ${ }^{15} \mathrm{NH}_{4}{ }^{+}$and $\mathrm{DO}^{15} \mathrm{~N}$ were measured in $2 \mathrm{~h}$ incubations that were initiated with the addition of ${ }^{15} \mathrm{~N}_{2}$ gas $(99 \%$ enriched) and terminated by gentle filtration through pre-combusted $\left(450^{\circ} \mathrm{C}\right.$ for $\left.2 \mathrm{~h}\right) \mathrm{GF} / \mathrm{F}$ filters. $\mathrm{NH}_{4}{ }^{+}$uptake and isotope dilution incubations were $1 \mathrm{~h}$. Both were in the linear range of uptake during time courses conducted separately (data not shown). All ${ }^{15} \mathrm{~N}$ rate samples were analyzed on a Europa Geo 20/20 mass spectrophotometer as described above.

$\mathrm{N}_{2}$ fixation rates were also estimated using the $\mathrm{C}_{2} \mathrm{H}_{2}$ reduction technique (Capone 1993). Assays were initiated by adding $1 \mathrm{ml}$ of $\mathrm{C}_{2} \mathrm{H}_{2}$ to the headspace of serum vials containing $10 \mathrm{ml}$ of culture. Immediately after the $\mathrm{C}_{2} \mathrm{H}_{2}$ addition and at 30 min increments over $2 \mathrm{~h}$, $500 \mu \mathrm{l}$ of headspace was removed and the production of ethylene was measured using a Shimadzu gas chromatograph. Ratios of 3:1 and 4:1 were used to convert rates of ethylene production $\left(\mathrm{C}_{2} \mathrm{H}_{2}\right.$ reduction) to $\mathrm{N}_{2}$ fixation (Montoya et al. 1996). Both of these ratios have been used in previous studies. While 3:1 is the theoret- 


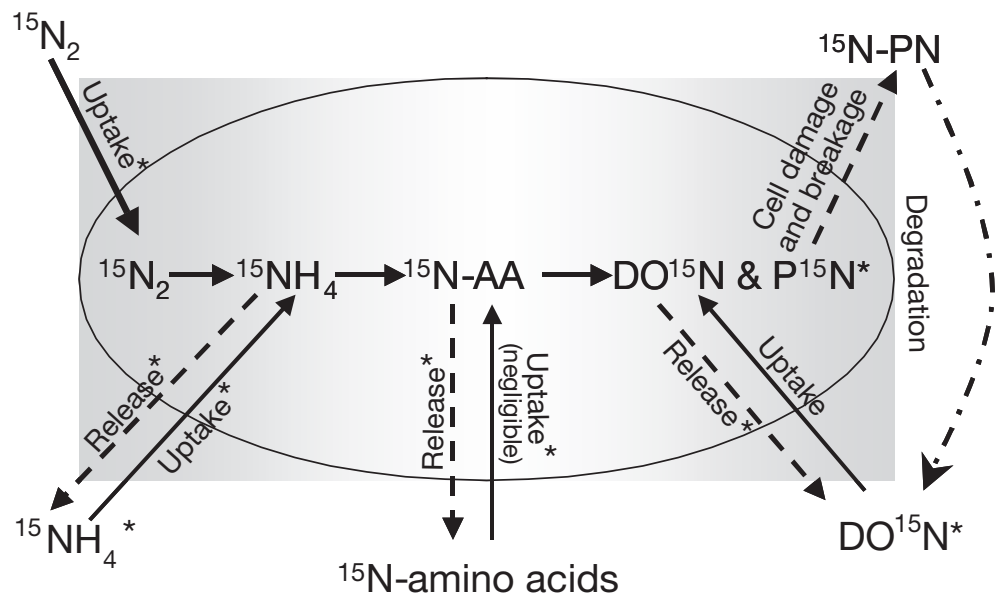

*Indicates pools and pathways being measured

Fig. 2. Pools and pathways measured using ${ }^{15} \mathrm{~N}$ tracers

ical ratio of $\mathrm{mol} \mathrm{C}_{2} \mathrm{H}_{2}$ reduced per mol $\mathrm{N}_{2}$, the $4: 1$ ratio is often considered more appropriate (see Capone 1988, 1993, Montoya et al. 1996, Postgate 1998). For Trichodesmium, average deviations in the $\mathrm{C}_{2} \mathrm{H}_{2}: \mathrm{N}_{2}$ reduction ratio range from 3:1 to 9.3:1 in 3 to $6 \mathrm{~h}$ incubations of natural populations (Montoya et al. 1996). Deviations between $\mathrm{C}_{2} \mathrm{H}_{2}$ reduction and ${ }^{15} \mathrm{~N}_{2}$ uptakebased estimates of $\mathrm{N}_{2}$ fixation were assessed relative to measured rates of $\mathrm{N}$ release and $\mathrm{N}$ regeneration by isotope dilution.

Recovery of ${ }^{15} \mathrm{~N}_{2}$ in particulate and dissolved pools $\left(\mathrm{NH}_{4}{ }^{+}\right.$and DON) was measured to determine whether the ratio of $\mathrm{C}_{2} \mathrm{H}_{2}$ reduction to total ${ }^{15} \mathrm{~N}_{2}$ uptake could serve as a secondary measure of the release of recently fixed $\mathrm{N}_{2}$ (see Fig. 2 for measured pools/pathways). If there were significant short-term release of recently fixed $\mathrm{N}_{2},{ }^{15} \mathrm{~N}_{2}$ uptake to PON would underestimate total $\mathrm{N}_{2}$ fixation.

\section{RESULTS}

\section{Biomass and cellular pools}

The doubling time for these cultures was about $5 \mathrm{~d}$, which is similar to growth rates reported in previous studies (see Mulholland \& Capone 2001 for a summary). Growth rates were estimated using 3 indices of biomass: chl $a$, number of filaments and PON (Fig. 3). All the indices had the same temporal pattern and cultures achieved their peak biomass at $15 \mathrm{~d}$. $\mathrm{NH}_{4}{ }^{+}$accumulated to concentrations of up to $1.5 \mu \mathrm{mol} \mathrm{l}^{-1}$ in the medium during the first $5 \mathrm{~d}$ of growth, but by Day 15 concentrations were comparable to those measured at the outset of the experiment $\left(0.6 \mu \mathrm{mol} \mathrm{l}^{-1}\right)$ (Fig. 4). DFAA concentrations remained low $\left(<0.2 \mu \mathrm{mol} \mathrm{l}^{-1}\right)$ during the $15 \mathrm{~d}$ that culture biomass increased. DON concentrations, however, increased after Day 11.

Intracellular concentrations of $\mathrm{NH}_{4}^{+}$and DFAA ranged from 0.07 to $0.74 \mathrm{nmol} \mathrm{filament}^{-1}$ $\left(\approx 0.7\right.$ to $7.4 \mathrm{pmol} \mathrm{cell}^{-1}$, based on an average of 100 cells filament ${ }^{-1}$ ) and 0.13 to $1.5 \mathrm{nmol}$ filament $^{-1} \approx \approx 1.3$ to 15 pmol cell $^{-1}$, based on an average of 100 cells filament $^{-1}$ ), respectively (Fig. 4). There was a declining trend in intracellular $\mathrm{NH}_{4}^{+}$concentrations over the growth period, while intracellular DFAA pools were higher during early and mid-exponential growth phases.

\section{$N_{2}$ fixation and release of recently fixed $N_{2}$}

Rates of $\mathrm{N}_{2}$ fixation estimated using the $\mathrm{C}_{2} \mathrm{H}_{2}$ reduction assay and the conventional conversion factor of 3:1 exceeded rates of net ${ }^{15} \mathrm{~N}_{2}$ uptake during most of the growth cycle (Table 1, Fig. 5). During the outset of the experiment, when biomass was very low, $\mathrm{C}_{2} \mathrm{H}_{2}$ reduction estimates were slightly less than or about equal to rates of net ${ }^{15} \mathrm{~N}_{2}$ uptake into particulate matter retained on the GF/F filter (and presumably in cells) at the end of the incubation. These estimates diverged later in the growth cycle with $\mathrm{C}_{2} \mathrm{H}_{2}$ reduction, based on a constant 3:1 ratio, exceeding net ${ }^{15} \mathrm{~N}_{2}$ uptake by a factor of 2 to 3 .

Divergences between estimates of nitrogenase activity measured by $\mathrm{C}_{2} \mathrm{H}_{2}$ reduction and ${ }^{15} \mathrm{~N}_{2}$ uptake have been previously related to the fact that the natural hydrogenase activity of nitrogenase while fixing $\mathrm{N}_{2}$ is greatly reduced in the presence of $\mathrm{C}_{2} \mathrm{H}_{2}$, resulting in reducing equivalents being shunted to $\mathrm{C}_{2} \mathrm{H}_{2}$ reduction (Scranton 1984, Scranton et al. 1987, Postgate 1998). The divergence in rate estimates for $\mathrm{N}_{2}$ fixation esti-

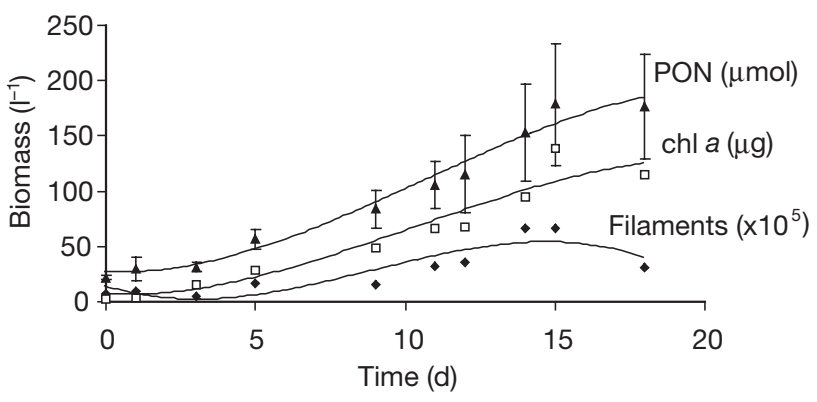

Fig. 3. Accumulation of chlorophyll a $(\mathrm{chl} a)$, filaments and particulate organic $\mathrm{N}$ (PON) in batch culture of Trichodesmium IMS101 growing on medium without added $\mathrm{N}$ sources over an $18 \mathrm{~d}$ growth period. Error bars represent standard deviations from replicate cultures 


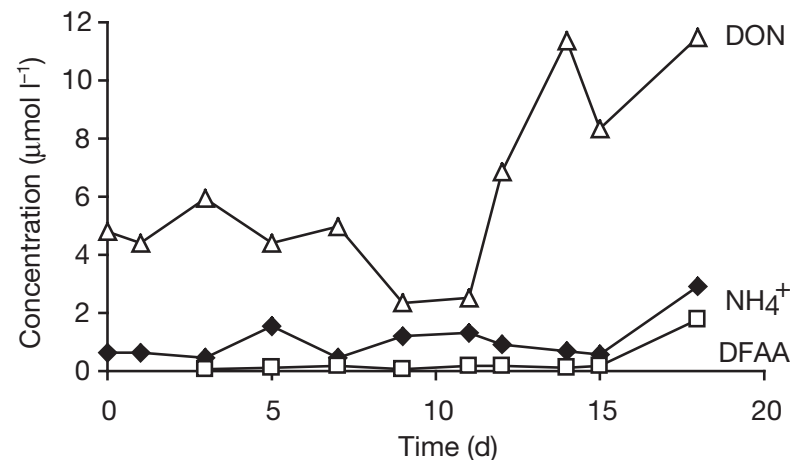

Fig. 4. Accumulation of $\mathrm{NH}_{4}{ }^{+}$, dissolved free amino acids (DFAA) and dissolved organic nitrogen (DON) in the culture medium of Trichodesmium IMS101 growing in batch culture on medium without added $\mathrm{N}$ sources, over the course of an 18 d growth cycle. Replicate samples were not collected. Standard deviations from replicate injections were $<10 \%$ and so are not shown

mated using $\mathrm{C}_{2} \mathrm{H}_{2}$ reduction versus ${ }^{15} \mathrm{~N}_{2}$ uptake methods might also be due to the release of recently fixed $\mathrm{N}_{2}$ as DON or $\mathrm{NH}_{4}{ }^{+}$. However, estimated rates of $\mathrm{NH}_{4}{ }^{+}$ and DON production from ${ }^{15} \mathrm{~N}_{2}$ were also low compared with net ${ }^{15} \mathrm{~N}_{2}$ uptake and $\mathrm{C}_{2} \mathrm{H}_{2}$ reduction throughout the growth cycle (Table 1) and relative to previous field estimates (Capone et al. 1994, Glibert \& Bronk 1994). When rates of $\mathrm{NH}_{4}{ }^{+}$and DON production were added to net ${ }^{15} \mathrm{~N}_{2}$ uptake, to estimate total ${ }^{15} \mathrm{~N}_{2}$ uptake, this value was generally still much lower than estimates of $\mathrm{C}_{2} \mathrm{H}_{2}$ reduction when assuming a 3:1 ratio throughout the experiment (Fig. 5). However, using a 4:1 ratio brings the $\mathrm{C}_{2} \mathrm{H}_{2}$ reduction and ${ }^{15} \mathrm{~N}_{2}$-based estimates much closer in line with total ${ }^{15} \mathrm{~N}_{2}$ fixation for Days 3 through 18 (Fig. 5, Table 1).
We derived an empirical conversion ratio for each time point by comparing the $\mathrm{C}_{2} \mathrm{H}_{2}$ reduction rate directly to the net ${ }^{15} \mathrm{~N}_{2}$ uptake and total ${ }^{15} \mathrm{~N}_{2}$ uptake (the sum of net ${ }^{15} \mathrm{~N}_{2}$ uptake and ${ }^{15} \mathrm{NH}_{4}{ }^{+}$and $\mathrm{DO}^{15} \mathrm{~N}$ production) (Table 1). In general, estimates were relatively close to the theoretical 3:1 ratio only on Day 1. In late exponential and early stationary phase, the 2 estimates likely diverge because of considerable release of $\mathrm{NH}_{4}{ }^{+}$and DON.

A summation of total $\mathrm{N}$ accumulated in the particulate and dissolved pools was also calculated for the cultures. There was an accumulation of $162 \mu \mathrm{mol} \mathrm{l}^{-1}$ total $\mathrm{N}$ (PON, DON and $\mathrm{NH}_{4}^{+}$) over the $18 \mathrm{~d}$ experiment based on changes in these concentrations. Rates of net ${ }^{15} \mathrm{~N}_{2}$ uptake and ${ }^{15} \mathrm{NH}_{4}{ }^{+}$and $\mathrm{DO}^{15} \mathrm{~N}$ production were

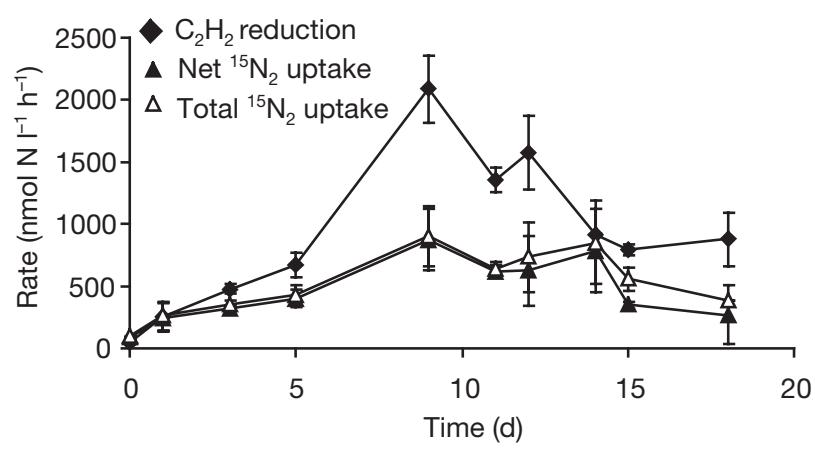

Fig. 5. Rates of $\mathrm{N}_{2}$ fixation estimated from net ${ }^{15} \mathrm{~N}_{2}$ uptake (uptake of ${ }^{15} \mathrm{~N}_{2}$ into PON collected on a GF/F filter at the end of the incubation); acetylene $\left(\mathrm{C}_{2} \mathrm{H}_{2}\right)$ reduction (conversion factor of 3:1); and total ${ }^{15} \mathrm{~N}_{2}$ uptake estimated by adding the rates of net ${ }^{15} \mathrm{~N}_{2}$ uptake, $\mathrm{DO}{ }^{15} \mathrm{~N}$ production and ${ }^{15} \mathrm{NH}_{4}{ }^{+}$production in batch cultures of Trichodesmium IMS101 growing on medium without added combined N. Error bars indicate standard deviations from replicate cultures

Table 1. Comparison of rates of $\mathrm{N}_{2}$ fixation estimated using acetylene $\left(\mathrm{C}_{2} \mathrm{H}_{2}\right)$ reduction, and conversion factors of 3 or 4 , with rates of ${ }^{15} \mathrm{~N}_{2}$ uptake, ${ }^{15} \mathrm{NH}_{4}{ }^{+}$and $\mathrm{DO}^{15} \mathrm{~N}$ production, and ${ }^{15} \mathrm{NH}_{4}{ }^{+}$uptake with estimates of $\mathrm{NH}_{4}{ }^{+}$regeneration from isotope dilution corrected (IDC). Units are $n m o l ~ ~^{-1} \mathrm{~h}^{-1}$. The ratios of $\mathrm{N}_{2}$ fixation estimated by the acetylene reduction (AR) method and net or total ${ }^{15} \mathrm{~N}_{2}$ uptake are also compared. Standard deviation of replicate measurements in parentheses; na: no standard deviation was available

\begin{tabular}{|c|c|c|c|c|c|c|c|c|c|c|c|}
\hline \multirow[t]{2}{*}{ Day } & \multicolumn{2}{|c|}{$\mathrm{C}_{2} \mathrm{H}_{2}$ reduction } & \multirow{2}{*}{$\begin{array}{c}\text { Net }{ }^{15} \mathrm{~N}_{2} \\
\text { uptake } \\
\text { (A) }\end{array}$} & \multirow{2}{*}{$\begin{array}{c}{ }^{15} \mathrm{NH}_{4}^{+} \\
\text {production } \\
\text { (B) }\end{array}$} & \multirow{2}{*}{$\begin{array}{c}\mathrm{DO}^{15} \mathrm{~N} \\
\text { production } \\
\text { (C) }\end{array}$} & \multirow{2}{*}{$\begin{array}{c}\text { Total }{ }^{15} \mathrm{~N}_{2} \\
\text { uptake } \\
(\mathrm{A}+\mathrm{B}+\mathrm{C})\end{array}$} & \multirow{2}{*}{$\begin{array}{l}{ }^{15} \mathrm{NH}_{4}^{+} \\
\text {uptake }\end{array}$} & \multicolumn{2}{|c|}{ IDC ${ }^{15} \mathrm{NH}_{4}^{+}$} & \multicolumn{2}{|c|}{ Ratio of AR to } \\
\hline & $3: 1$ ratio & $4: 1$ ratio & & & & & & uptake & $\begin{array}{l}\text { regen- } \\
\text { eration }\end{array}$ & net $\mathrm{N}_{2}{ }^{\mathrm{a}}$ & total $\mathrm{N}_{2}{ }^{\mathrm{a}}$ \\
\hline 0 & $48.7(17)$ & $36.5(13)$ & $84(4.6)$ & $5.3(1.1)$ & $6.4(3.1)$ & 95.7 & 489 (65) & & & 1.74 & 1.53 \\
\hline 1 & $249(7.4)$ & $187(5.6)$ & 246 (117) & $7.0(0.8)$ & $6.2(1.5)$ & 259.2 & 561 (336) & 708 (na) & 1564 & 3.04 & 2.88 \\
\hline 3 & $479(36)$ & $359(27)$ & $319(22)$ & $25.7(25)$ & $10.9(5.1)$ & 355.6 & $402(56)$ & $457(63)$ & 479 & 4.50 & 4.04 \\
\hline 5 & $672(101)$ & $504(76)$ & $401(72)$ & $21.3(4.5)$ & $6.9(0.9)$ & 429.2 & 925 (381) & $1120(462)$ & 1937 & 5.03 & 4.70 \\
\hline 9 & 2087 (267) & 1565 (200) & $875(246)$ & $14.0(5.7)$ & $13.2(0.5)$ & 902.2 & 817 (535) & $2982(1950)$ & 3015 & 7.16 & 6.94 \\
\hline 11 & 1356 (97) & $1017(73)$ & $620(51)$ & $10.7(1.2)$ & $11.8(6.5)$ & 642.5 & 641 (566) & $1642(1450)$ & 3335 & 6.56 & 6.33 \\
\hline 12 & $1572(298)$ & $1179(224)$ & $624(278)$ & $9.2(0.2)$ & $99.7(1.4)$ & 732.9 & 399 (na) & 756 (na) & 2048 & 7.56 & 6.43 \\
\hline 14 & 918 (13) & $689(10)$ & 786 (335) & $8.2(0.1)$ & $57.5(19.4)$ & 851.7 & $497(141)$ & $647(184)$ & 841 & 3.50 & 3.23 \\
\hline 15 & 791 (42) & $593(32)$ & $349(25)$ & $9.3(3.3)$ & $198(86)$ & 556.3 & 436 (114) & 595 (155) & 695 & 6.80 & 4.27 \\
\hline 18 & 879 (213) & $659(160)$ & $269(237)$ & 72.9 (na) & 42.2 (na) & 384.1 & $1315(69)$ & $3584(187)$ & 7428 & 9.80 & 6.87 \\
\hline
\end{tabular}


integrated over the growth curve, interpolating between days on which no measurements were made and assuming these rates occurred over the $12 \mathrm{~h}$ light period (Fig. 6). Total ${ }^{15} \mathrm{~N}_{2}$ uptake (into particulate matter and recovered in the dissolved $\mathrm{NH}_{4}{ }^{+}$and DON pools) could account for $125 \mu \mathrm{mol} \mathrm{l}^{-1} \mathrm{~N}$ of this accumulation. The rate measurements likely underestimate net $\mathrm{N}$ accumulation, but they were within the combined error of measurements made on replicate cultures, suggesting that ${ }^{15} \mathrm{~N}_{2}$ uptake and release of recently fixed $\mathrm{N}_{2}$ could account for $\mathrm{N}$ dynamics in cultures. Integrated $\mathrm{N}_{2}$ fixation, estimated using $\mathrm{C}_{2} \mathrm{H}_{2}$ reduction with a 3:1 ratio, introduced $225 \mu \mathrm{mol} \mathrm{N} \mathrm{l^{-1 }}$ new $\mathrm{N}$ to the culture system during this experiment, whereas assuming a 4:1 ratio yielded a value of $169 \mu \mathrm{mol} \mathrm{N}{ }^{-1}$, very close to that observed (Fig. 6).

Accumulation of PON estimated using total ${ }^{15} \mathrm{~N}_{2}$ uptake closely paralleled the observed growth rates in the cultures, while $\mathrm{C}_{2} \mathrm{H}_{2}$ reduction-based estimates of PON accumulation were faster than the observed growth rates during most of the experiment (after Day 3).

\section{$\mathrm{NH}_{4}{ }^{+}$uptake, regeneration and isotope dilution}

Despite the low estimates of $\mathrm{NH}_{4}{ }^{+}$production from ${ }^{15} \mathrm{~N}_{2}$, rates of $\mathrm{NH}_{4}{ }^{+}$uptake were comparable to or higher than rates of ${ }^{15} \mathrm{~N}_{2}$ uptake during exponential growth (Table 1). When corrected for isotope dilution (see Glibert et al. 1982, Glibert \& Capone 1993), uptake of $\mathrm{NH}_{4}{ }^{+}$exceeded rates of ${ }^{15} \mathrm{~N}_{2}$ uptake and were often comparable to rates of $\mathrm{N}_{2}$ fixation estimated by $\mathrm{C}_{2} \mathrm{H}_{2}$ reduction (Table 1 ). Unlike estimates of ${ }^{15} \mathrm{NH}_{4}{ }^{+}$release from ${ }^{15} \mathrm{~N}_{2}$ uptake, rates of $\mathrm{NH}_{4}{ }^{+}$regen-

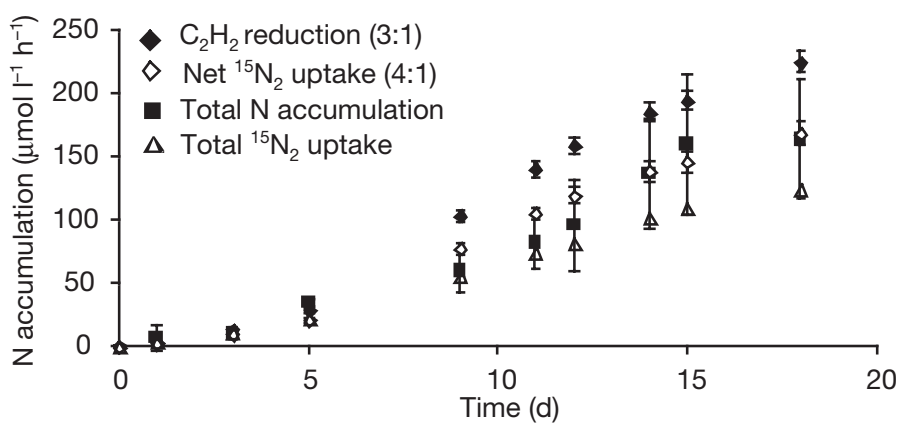

Fig. 6. Total accumulation of $\mathrm{N}$ in culture vessels over the course of the growth cycle estimated from acetylene reduction (using conversion factors of 3 and 4 ), total ${ }^{15} \mathrm{~N}_{2}$ uptake (estimated by adding the rates of net ${ }^{15} \mathrm{~N}_{2}$ uptake, DO ${ }^{15} \mathrm{~N}$ production and ${ }^{15} \mathrm{NH}_{4}{ }^{+}$production), and the observed accumulation of total $\mathrm{N}$ (estimated by adding PON plus total dissolved N) in batch cultures of Trichodesmium IMS101 growing on medium without added combined N. Error bars indicate standard deviations from replicate cultures eration estimated using the isotope dilution method were substantial and exceeded rates of ${ }^{15} \mathrm{NH}_{4}{ }^{+}$production from recently fixed ${ }^{15} \mathrm{~N}_{2}$ by up to 2 orders of magnitude. Rates of $\mathrm{NH}_{4}{ }^{+}$uptake corrected for isotope dilution were comparable to rates of regeneration of $\mathrm{NH}_{4}{ }^{+}$ from isotope dilution (Table 1), indicating rapid turnover and a tight coupling between $\mathrm{NH}_{4}{ }^{+}$uptake and release and consistent with the observation that $\mathrm{NH}_{4}{ }^{+}$did not accumulate in the culture medium (Fig. 4).

\section{DISCUSSION}

\section{Trichodesmium uptake of $\mathrm{NH}_{4}{ }^{+}$and DON}

Early tracer studies suggested that Trichodesmium spp. had a relatively low capacity for uptake of combined N (Carpenter \& McCarthy 1975, Glibert \& Banahan 1988) and were primarily dependent upon $\mathrm{N}_{2}$ fixation to meet their N nutritional needs. Subsequent work, however, has found a relatively high capacity for $\mathrm{NH}_{4}{ }^{+}$assimilation in field populations and cultures (Mulholland \& Capone 1999, 2000, Mulholland et al. 1999) although stable isotope (Carpenter et al. 1997) and culture studies (Mulholland \& Capone 2001) still indicate that net growth is largely supported by $\mathrm{N}_{2}$ fixation. Adding to the complexity, high rates of DON release from recently fixed $\mathrm{N}_{2}$ have been observed in field studies (Capone et al. 1994, Glibert \& Bronk 1994) and release of $\mathrm{NH}_{4}{ }^{+}$has been inferred, but not directly measured, in culture studies (Prufert-Bebout et al. 1993, Mulholland \& Capone 2001). In order to obtain a broader understanding of $\mathrm{N}$ dynamics and metabolism by these organisms, we examined rates of $\mathrm{NH}_{4}{ }^{+}$and DON release from ${ }^{15} \mathrm{~N}_{2}$ uptake experiments, in parallel with estimates of $\mathrm{N}_{2}$ fixation using the $\mathrm{C}_{2} \mathrm{H}_{2}$ reduction technique, and $\mathrm{NH}_{4}{ }^{+}$ uptake and regeneration from isotope dilution in Trichodesmium cultures.

Like previous culture and field studies (Mulholland \& Capone 1999, 2001, Mulholland et al. 1999), we observed rates of $\mathrm{NH}_{4}{ }^{+}$uptake that were comparable to or higher than rates of $\mathrm{N}_{2}$ fixation estimated by $\mathrm{C}_{2} \mathrm{H}_{2}$ reduction. These high uptake rates are consistent with the stoichiometric imbalance between $\mathrm{CO}_{2}$ fixation and $\mathrm{N}_{2}$ fixation over a growth cycle (Mulholland \& Capone 2001). Additional $\mathrm{N}$ turnover from $\mathrm{NH}_{4}{ }^{+}$regeneration and uptake within the culture vessels would not support net growth but could balance $\mathrm{CO}_{2}$ fixation in excess of that necessary to support the observed $\mathrm{C}$ accumulation as biomass. Alternatively, as we have previously speculated, the release and subsequent uptake of $\mathrm{NH}_{4}{ }^{+}$or other fixed $\mathrm{N}$ compounds may be a mechanism 
whereby fixed $\mathrm{N}$ is transferred between cells capable of fixing $\mathrm{N}_{2}$ and those that are not (Mulholland \& Capone 1999, 2000), as might be required by the cyanocyte model which argues that only a subset of the cells of a trichome are induced for $\mathrm{N}_{2}$ fixation (BermanFrank et al. 2001).

Based on our results from ${ }^{15} \mathrm{~N}_{2}$ uptake experiments, the high rates of $\mathrm{NH}_{4}{ }^{+}$uptake observed in cultures of Trichodesmium cannot be supported by the measured release of recently fixed ${ }^{15} \mathrm{~N}_{2}$ as ${ }^{15} \mathrm{NH}_{4}{ }^{+}$. In contrast, high rates of $\mathrm{NH}_{4}{ }^{+}$regeneration from isotope dilution suggest that in fact, release rates are substantial and that release and uptake are tightly coupled in these culture systems. The lack of $\mathrm{NH}_{4}{ }^{+}$accumulation in the growth medium over most of the growth cycle supports this, and the tight coupling precludes accurate estimates of gross $\mathrm{NH}_{4}{ }^{+}$release based on quantifying the accumulation of ${ }^{15} \mathrm{~N}$ label in the $\mathrm{NH}_{4}{ }^{+}$pool during ${ }^{15} \mathrm{~N}_{2}$ uptake studies.

\section{Release of $\mathrm{NH}_{4}{ }^{+}$and DON}

In contrast to 2 field studies (Capone et al. 1994, Glibert \& Bronk 1994, O'Neil et al. 1996), observed rates of ${ }^{15} \mathrm{NH}_{4}{ }^{+}$and $\mathrm{DO}^{15} \mathrm{~N}$ production from recently fixed ${ }^{15} \mathrm{~N}_{2}$ were low in the cultures. We discuss 2 potential reasons for these low rates: (1) the absence of grazers in the cultures; and (2) the presence of large intracellular pools of $\mathrm{NH}_{4}{ }^{+}$and DON in cultured Trichodesmium.

The presence of grazers and associated sloppy feeding is an important mechanism for the release of regenerated N (Bronk 2002). Rates of DON release were found to be significantly higher in the presence of grazers in California coastal waters and DON release rates were closely correlated to $\mathrm{NH}_{4}{ }^{+}$regeneration (Ward \& Bronk 2001). One grazer, the harpacticoid copepod Macrosetella gracilis, has been shown to feed on Trichodesmium colonies (O'Neil \& Roman 1992, O'Neil 1998). These copepods do not appear to make solid fecal pellets such that most of the $\mathrm{N}$ they release remains in the dissolved fraction (O'Neil et al. 1996). Therefore, one likely reason for the lower rates of $\mathrm{N}$ release in this culture study was the absence of grazers.

Another contributing factor to the low rates of $\mathrm{N}$ release in the cultures may have been the presence of large intracellular pools of unlabeled $\mathrm{NH}_{4}{ }^{+}$and DON compounds (e.g. DFAA). Initial $\mathrm{NH}_{4}{ }^{+}$and DON release may have been isotopically light material that was present in cells prior to the ${ }^{15} \mathrm{~N}_{2}$ addition. Based on rates of total $\mathrm{N}_{2}$ uptake, it would have taken less than one to several hours to turn over the intracellular $\mathrm{NH}_{4}{ }^{+}$pool (Table 2) and, in most cases, even longer to turn over the intracellular DFAA pool. Hence, $2 \mathrm{~h}$ incubations may have been insufficient for the intermediate internal $\mathrm{NH}_{4}{ }^{+}$to reach isotopic equilibrium with the initial ${ }^{15} \mathrm{~N}_{2}$ tracer pool, thereby precluding accurate estimation of ${ }^{15} \mathrm{NH}_{4}{ }^{+}$or $\mathrm{DO}^{15} \mathrm{~N}$ release rate. Similarly, $\mathrm{NH}_{4}{ }^{+}$regeneration based on isotope dilution can also be underestimated if the intracellular pools are emptied in less than the $1 \mathrm{~h}$ incubation period because ${ }^{15} \mathrm{NH}_{4}{ }^{+}$taken up might be released. The total intracellular DON pools were not measured, but intracellular DFAA pools were often much larger than intracellular $\mathrm{NH}_{4}{ }^{+}$pools (e.g. Table 2) and so similar problems could have resulted in underestimates of $D{ }^{15} \mathrm{~N}$ release from ${ }^{15} \mathrm{~N}_{2}$ uptake.

While these observations were made in cultured populations, we previously measured intracellular pools

Table 2. Comparison of trichome-specific $\mathrm{N}_{2}$ fixation rates, intracellular $\mathrm{NH}_{4}{ }^{+}$and $\mathrm{PON}$ pools and turnover of intracellular pools of $\mathrm{NH}_{4}{ }^{+}\left(\mathrm{IN}-\mathrm{NH}_{4}{ }^{+}\right)$and PON based on $\mathrm{N}_{2}$ fixation estimates. Standard deviations of replicate measurements in parentheses

\begin{tabular}{|c|c|c|c|c|c|c|c|c|c|c|}
\hline \multirow[t]{2}{*}{ Day } & \multicolumn{2}{|c|}{$\begin{array}{c}\mathrm{C}_{2} \mathrm{H}_{2} \text { reduction } \\
\left(\text { nmol } \mathrm{N} \text { trichome }{ }^{-1} \mathrm{~h}^{-1}\right)\end{array}$} & \multirow{2}{*}{$\begin{array}{l}\text { Total }{ }^{15} \mathrm{~N}_{2} \\
\text { uptake } \\
(\text { nmol N } \\
\left.\text { trichome }{ }^{-1}\right)\end{array}$} & \multirow{2}{*}{$\begin{array}{c}{\mathrm{IN}-\mathrm{NH}_{4}{ }^{+}}_{\text {pool }} \\
(\mathrm{nmol} \mathrm{N} \\
\left.\text { trichome }{ }^{-1} \mathrm{~h}^{-1}\right)\end{array}$} & \multirow{2}{*}{$\begin{array}{c}\text { IN-DFAA } \\
\text { pool } \\
(\mathrm{nmol} \mathrm{N} \\
\left.\text { trichome }^{-1}\right)\end{array}$} & \multirow{2}{*}{$\begin{array}{c}\text { PON } \\
\text { pool } \\
\left(\mathrm{nmol} \mathrm{N}^{-}\right. \\
\text {trichome } \\
\text { t-1 })\end{array}$} & \multirow{2}{*}{\multicolumn{2}{|c|}{$\begin{array}{c}\mathrm{Tu} \\
{\mathrm{N}-\mathrm{NH}_{4}^{+}}^{+} \\
\mathrm{pool}^{\mathrm{a}} \mathrm{pool}^{\mathrm{b}} \\
\text { (h) }\end{array}$}} & \multicolumn{2}{|c|}{ PON } \\
\hline & $3: 1$ & $4: 1$ & & & & & & & $\begin{array}{l}\text { pool }^{\mathrm{a}} \\
\text { (d) }\end{array}$ & $\begin{array}{c}\text { pool }^{\text {b }} \\
\text { (d) }\end{array}$ \\
\hline 0 & $0.117(0.040)$ & $0.088(0.030)$ & 0.229 & 0.48 & & $52.2(3.6)$ & 4.1 & 2.1 & & \\
\hline 1 & $0.359(0.011)$ & $0.269(0.008)$ & 0.373 & 0.74 & & $42.6(14.9)$ & 2.1 & 2.0 & 4.9 & 4.8 \\
\hline 3 & $0.492(0.037)$ & $0.369(0.028)$ & 0.366 & 0.47 & 0.74 & $31.9(4.4)$ & 1.0 & 1.3 & 2.7 & 3.6 \\
\hline 5 & $0.404(0.060)$ & $0.303(0.045)$ & 0.258 & 0.45 & 0.44 & 33.8 (1.9) & 1.1 & 1.7 & 3.5 & 5.5 \\
\hline 9 & $1.37 \quad(0.175)$ & $1.028(0.131)$ & 0.590 & 0.36 & 1.50 & $54.8(11.0)$ & 0.3 & 0.6 & 1.7 & 3.9 \\
\hline 11 & $0.425(0.030)$ & $0.319(0.023)$ & 0.201 & 0.15 & 0.63 & $33.1(6.8)$ & 0.4 & 0.7 & 3.2 & 6.9 \\
\hline 12 & $0.435(0.082)$ & $0.326(0.062)$ & 0.203 & 0.41 & 0.49 & $31.9(9.8)$ & 0.9 & 2.0 & 3.1 & 6.5 \\
\hline 14 & $0.138(0.002)$ & $0.104(0.002)$ & 0.128 & 0.27 & 0.46 & $22.9(6.5)$ & 2.0 & 2.1 & 6.9 & 7.5 \\
\hline 15 & $0.119(0.006)$ & 0.089 (0.005) & 0.083 & 0.07 & 0.13 & $26.7(8.3)$ & 0.6 & 0.8 & 9.4 & 13.4 \\
\hline 18 & $0.288(0.070)$ & & 0.126 & 0.08 & 0.13 & $57.8(15.5)$ & 0.3 & 0.6 & 8.4 & 19.1 \\
\hline
\end{tabular}


of DFAA and $\mathrm{NH}_{4}{ }^{+}$in natural populations of Trichodesmium (Mulholland et al. 1999). During those studies, intracellular pool concentrations were much lower (maximum of about $0.03 \mathrm{nmol} \mathrm{NH}_{4}{ }^{+}$filament ${ }^{-1}$ and $0.06 \mathrm{nmol}$ DFAA filament ${ }^{-1}$ ) than in this culture study, where the medium was nutrient replete (with respect to $\mathrm{P}$ and trace elements). However, biomass-specific $\mathrm{N}_{2}$ fixation rates are often lower and $\mathrm{N}$-based turnover times longer in field studies (Mulholland \& Capone 2000), and so these pools might still be sufficiently large to cause underestimates in $\mathrm{N}$ release from ${ }^{15} \mathrm{~N}_{2}$ uptake experiments for the reasons discussed above.

Simultaneous release and uptake of $\mathrm{NH}_{4}{ }^{+}$or DON on time-scales shorter than the incubation period would also bias both the measurements of ${ }^{15} \mathrm{NH}_{4}{ }^{+}$or $\mathrm{DO}^{15} \mathrm{~N}$ production from ${ }^{15} \mathrm{~N}_{2}$ uptake and $\mathrm{NH}_{4}{ }^{+}$regeneration by the isotope dilution method because released material would not accumulate in the growth media. Correcting uptake calculations for isotope dilution yields much higher uptake rates than those derived without this correction (Table 1). $\mathrm{NH}_{4}^{+}$uptake was often higher than total $\mathrm{N}_{2}$ fixation, particularly in the initial growth phases. Tightly coupled release and uptake of $\mathrm{NH}_{4}{ }^{+}$is supported by the observed $\mathrm{NH}_{4}{ }^{+}$concentrations, the high rates of $\mathrm{NH}_{4}{ }^{+}$regeneration from isotope dilution, and the absence of sustained $\mathrm{NH}_{4}{ }^{+}$accumulation over the growth cycle.

Tightly coupled release and uptake was likely the case for DON as well; however, no independent measure of DON regeneration was made. For DON, there is the additional problem of identifying the relevant production pool. For example, an earlier study suggested that the primary organic compounds released by Trichodesmium were DFAA (Capone et al. 1994).

\section{Comparing ${ }^{15} \mathrm{~N}_{2}$ uptake with $\mathrm{C}_{2} \mathrm{H}_{2}$ reduction}

One important component of the present study is the comprehensive analysis of ${ }^{15} \mathrm{~N}$ products from ${ }^{15} \mathrm{~N}_{2}$ uptake done in parallel with $\mathrm{C}_{2} \mathrm{H}_{2}$ reduction determinations. As has been previously suggested (Carpenter 1973, Karl et al. 2002), we submit, and provide evidence to support, that $\mathrm{C}_{2} \mathrm{H}_{2}$ reduction provides an estimate of gross $\mathrm{N}_{2}$ fixation, as it should assay all nitrogenase activity, whereas ${ }^{15} \mathrm{~N}_{2}$ uptake into particulate matter provides an estimate of net $\mathrm{N}_{2}$ fixation. Having simultaneous determination of ${ }^{15} \mathrm{NH}_{4}{ }^{+}$and $\mathrm{DO}^{15} \mathrm{~N}$ production, we can rigorously evaluate deviations from theoretical conversion factors and interpret the basis for those deviations.

The relationship between ${ }^{15} \mathrm{~N}_{2}$ fixation and $\mathrm{C}_{2} \mathrm{H}_{2}$ reduction is dependent upon a number of factors. For one, nitrogenase-dependent $\mathrm{H}_{2}$ release, which is inhibited by $\mathrm{C}_{2} \mathrm{H}_{2}$, results in a theoretical stoichiomet- ric ratio of $\mathrm{C}_{2} \mathrm{H}_{2}$ reduction to ${ }^{15} \mathrm{~N}_{2}$ fixation of $3: 1$ (mol:mol) (Postgate 1998). However, many cyanobacteria, including Trichodesmium (Saino \& Hattori 1982, Scranton 1984, Scranton et al. 1987), have efficient uptake hydrogenases to recoup $\mathrm{H}_{2}$ lost during natural $\mathrm{N}_{2}$ fixation. This would drive the ratio closer to the theoretical 4:1 ratio.

Ratios of $\mathrm{C}_{2} \mathrm{H}_{2}$ reduction to net ${ }^{15} \mathrm{~N}_{2}$ uptake greater than that theoretically predicted may also be indicative of substantial $\mathrm{N}$ release from $\mathrm{N}_{2}$ fixation. High rates of $\mathrm{NH}_{4}{ }^{+}$regeneration from isotope dilution in this study suggests that the release of recently fixed $\mathrm{N}_{2}$ is more substantial than production of ${ }^{15} \mathrm{NH}_{4}{ }^{+}$from $\mathrm{N}_{2}$ would predict (for the reasons discussed above). Therefore, divergence of the $\mathrm{C}_{2} \mathrm{H}_{2}$ reduction:net ${ }^{15} \mathrm{~N}_{2}$ uptake ratio from the theoretical ratio of 3:1 in the field studies may indicate that there was release of recently fixed $\mathrm{N}_{2}$, especially where incubations were long. Extensive field studies (191 paired comparisons) suggest a mean ratio of $\mathrm{C}_{2} \mathrm{H}_{2}$ reduction to net ${ }^{15} \mathrm{~N}_{2}$ uptake of about 3.6:1 (D. G. Capone et al. unpubl.). This is consistent with the observations that recently fixed $\mathrm{N}_{2}$ is released as DON (e.g. Capone et al. 1994, Glibert \& Bronk 1994). In contrast, in an earlier culture study, $\mathrm{N}_{2}$ fixation estimated using $\mathrm{C}_{2} \mathrm{H}_{2}$ reduction and a ratio of 3:1 more closely predicted the increase in PON (Mulholland \& Capone 2001). Similarly, Orcutt et al. (2001) reported an average ratio of about $3: 1$, with considerable variance around that mean, for a multi-year study at the Bermuda Atlantic Time Series station.

\section{CONCLUSION}

The current findings suggest that ${ }^{15} \mathrm{~N}_{2}$ uptake approximates net $\mathrm{N}$-specific growth rates (Table 2, Fig. 6) while the $\mathrm{C}_{2} \mathrm{H}_{2}$ reduction technique is a good estimator of gross $\mathrm{N}_{2}$ fixation. When considering total ${ }^{15} \mathrm{~N}_{2}$ fixation (sum of PON plus released DON and $\mathrm{NH}_{4}{ }^{+}$), a conversion ratio of 4:1 is more appropriate for quantification of total $\mathrm{N}_{2}$ fixation when measured by $\mathrm{C}_{2} \mathrm{H}_{2}$ reduction than that derived using the theoretical 3:1 conversion factor. Indeed, the difference between estimates of gross $\mathrm{N}_{2}$ fixation, made using the $\mathrm{C}_{2} \mathrm{H}_{2}$ reduction technique and the theoretical 3:1 conversion factor, and net $\mathrm{N}_{2}$ fixation, made using ${ }^{15} \mathrm{~N}_{2}$, is a good indicator of $\mathrm{N}$ release from $\mathrm{N}_{2}$ fixation.

Acknowledgements. We thank L. Sprague and M. Sanderson for their help in the laboratory. This research was supported by NSF grant OCE 0095923 to M.R.M., OCE 0095940 to D.A.B., and OCE99-81545 and OCE99-81371 to D.G.C. This is contribution 2630 from the Virginia Institute of Marine Science, The College of William and Mary. The authors would also like to thank 2 anonymous reviewers for their comments on an earlier version of the manuscript. 


\section{LITERATURE CITED}

Berman-Frank I, Lundgren P, Chen YB, Küpper H, Kolber Z, Bergman B, Falkowski P (2001) Segregation of nitrogen fixation and oxygenic photosynthesis in the marine cyanobacterium Trichodesmium. Science 294:1534-1537

Bronk DA (2002) Dynamics of DON. In: Hansell DA, Carlson CA (eds) Biogeochemistry of marine dissolved organic matter. Academic Press, San Diego, CA, p 153-249

Bronk DA, Glibert PM (1991) A ${ }^{15} \mathrm{~N}$ tracer method for the measurement of dissolved organic nitrogen release by phytoplankton. Mar Ecol Prog Ser 77:171-182

Bronk DA, Glibert PM (1993) Contrasting patterns of dissolved organic nitrogen release by two size fractions of estuarine plankton during a period of rapid $\mathrm{NH}_{4}{ }^{+}$consumption and $\mathrm{NO}_{2}-$ production. Mar Ecol Prog Ser 96: 291-299

Bronk DA, Glibert PM, Malone TC, Banahan S, Sahlsten E (1998) Inorganic and organic nitrogen cycling in Chesapeake Bay: autotrophic versus heterotrophic processes and relationships to carbon flux. Aquat Microb Ecol 15: 177-189

Bronk DA, Lomas M, Glibert PM, Schukert KJ, Sanderson MP (2000) Total dissolved nitrogen analysis: comparisons between the persulfate, UV and high temperature oxidation method. Mar Chem 69:163-178

Capone DG (1988) Benthic nitrogen fixation. In: Blackburn $\mathrm{TH}$, Sorenson J (eds) Nitrogen cycling in coastal marine environments, SCOPE Series, Vol 33. J Wiley \& Sons, New York, p 85

Capone DG (1993) Determination of nitrogenase activity in aquatic samples using the acetylene reduction procedure. In: Kemp PF, Sherr BF, Sherr EB, Cole JJ (eds) Handbook of methods in aquatic microbial ecology. Lewis Publishers, Boca Raton, FL, p 621-631

Capone DG, Ferrier MD, Carpenter EJ (1994) Amino acid cycling in colonies of the planktonic marine cyanobacterium, Trichodesmium thiebautii. Appl Environ Microbiol 60:3989-3995

Carpenter EJ (1973) Nitrogen fixation by Oscillatoria (Trichodesmium) thiebautii in the southwestern Sargasso Sea. Deep-Sea Res 20:285-288

Carpenter EJ, McCarthy JJ (1975) Nitrogen fixation and uptake of combined nitrogenous nutrients by Oscillatoria (Trichodesmium) thiebautii in the western Sargasso Sea. Limnol Oceanogr 20:389-401

Carpenter EJ, Capone DG, Fry B, Harvey HR (1997) Biogeochemical tracers of the marine cyanobacterium Trichodesmium. Deep-Sea Res 44:27-38

Chen YB, Zehr JP, Mellon M (1996) Growth and nitrogen fixation of the diazotrophic filamentous nonheterocystous cyanobacterium Trichodesmium sp. IMS101 in defined media: evidence for a circadian rhythm. J Phycol 32: 916-923

Cowie GL, Hedges JI (1992) Improved amino acid quantification in environmental samples: charged-matched recovery standards and reduced analysis time. Mar Chem 37: 223-238

Dudek N, Brezinski MA, Wheeler P (1986) Recovery of ammonium nitrogen by solvent extraction for the determination of relative $\mathrm{N}^{15}$ abundance in regeneration experiments. Mar Chem 18:59-69

Friederich GO, Whitledge TE (1972) Autoanalyzer procedures for nutrients. In: Pavlou SP (ed) Phytoplankton growth dynamics, Vol 1. University of Washington Special Report 52, Seattle, WA, p 37-55

Glibert PM, Banahan S (1988) Uptake of combined nitrogen sources by Trichodesmium and pelagic microplankton in the Caribbean Sea: comparative uptake capacity and nutritional status. EOS 69:1089

Glibert PM, Bronk DA (1994) Release of dissolved organic nitrogen by marine diazotrophic cyanobacteria, Trichodesmium spp. Appl Environ Microbiol 60:3996-4000

Glibert PM, Capone DG (1993) Mineralization and assimilation in aquatic sediment, and wetland systems. In: Knowles R, Blackburn TH (eds) Nitrogen isotope techniques. Academic Press, San Diego, CA, p 243-271

Glibert PM, Lipschultz F, McCarthy JJ, Altabet MA (1982) Isotope dilution models of uptake and remineralization of ammonium by marine plankton. Limnol Oceanogr 27: $639-650$

Hatch MJ, Dillon JA, Smith HB (1957) Preparation and use of snake-cage polyelectrolytes. Ind Eng Chem 49:1812-1818

Karl DM, Michaels A, Bergman B, Capone DG and 6 others (2002) Dinitrogen fixation in the world's oceans. Biogeochemistry 57:47-98

King GM, Berman T (1984) Potential effects of isotopic dilution on apparent respiration in ${ }^{14} \mathrm{C}$ heterotrophy experiments. Mar Ecol Prog Ser 19:175-180

Mackinney G (1941) Absorption of light by chlorophyll solutions. J Biol Chem 140:315-322

Montoya JP, Voss M, Kaehler P, Capone DG (1996) A simple, high precision tracer assay for dinitrogen fixation. Appl Environ Microbiol 62:986-993

Mulholland MR, Capone DG (1999) Nitrogen fixation, uptake and metabolism in natural and cultured populations of Trichodesmium spp. Mar Ecol Prog Ser 188:33-49

Mulholland MR, Capone DG (2000) The physiology of the marine $\mathrm{N}_{2}$ fixing cyanobacteria Trichodesmium. Trends Plant Sci 5:148-153

Mulholland MR, Capone DG (2001) The stoichiometry of N and $\mathrm{C}$ utilization in cultured populations of Trichodesmium IMS101. Limnol Oceanogr 46:436-443

Mulholland MR, Ohki K, Capone DG (1999) Nitrogen utilization and metabolism relative to patterns of $\mathrm{N}_{2}$ fixation cultures of Trichodesmium NIBB1067. J Phycol 35: 977-988

O'Neil JM (1998) The colonial cyanobacterium Trichodesmium as a physical and nutritional substrate for the harpacticoid copepod Macrosetella gracilis. J Plankton Res 20(1):43-59

O'Neil JM, Roman MR (1992) Grazers and associated organisms of Trichodesmium. In: Carpenter EJ, Capone DG, Reuter JG (eds) Marine pelagic cyanobacteria: Trichodesmium and other diazotrophs. Kluwer Academic Press, Dordrecht, p 61-73

O'Neil JM, Metzler PM, Glibert PM (1996) Ingestion of ${ }^{15} \mathrm{~N}_{2-}$ labelled Trichodesmium sp. and ammonium regeneration by the harpacticoid copepod Macrosetella gracilis. Mar Biol 125:89-96

Orcutt KM, Lipschultz F, Gundersen K, Arimoto R, Michaels AF, Knap AH, Gallon JR (2001) A seasonal study of the significance of $\mathrm{N}_{2}$ fixation by Trichodesmium spp. at the Bermuda Atlantic Time-series Study (BATS) site. DeepSea Res 48:1583-1608

Postgate JR (1998) The fundamentals of nitrogen fixation. Cambridge University Press, Cambridge

Prufert-Bebout L, Paerl HW, Lassen C (1993) Growth, nitrogen fixation, and spectral attenuation in cultivated Trichodesmium species. Appl Environ Microbiol 59: $1367-1375$

Saino T, Hattori A (1982) Aerobic nitrogen fixation by the marine non-heterocystous cyanobacterium Trichodesmium (Oscillatoria) spp.: its protective mechanism 
against oxygen. Mar Biol 70:251-254

Scranton MI (1984) Hydrogen cycling in the waters near Bermuda: the role of the nitrogen fixer, Oscillatoria thiebautii. Deep-Sea Res 31:133-143

Scranton MI, Novelli PC, Michaels A, Horrigan SG, Carpenter EJ (1987) Hydrogen production and nitrogen fixation by Oscillatoria thiebautii during in situ incubations. Limnol Oceanogr 32:998-1006

Thoresen SS, Dortch Q, Ahmed SI (1982) Comparison of

Editorial responsibility: Jed Fuhrman,

Los Angeles, California, USA methods for extracting intracellular pools of inorganic nitrogen from marine phytoplankton. J Plankton Res 4: 695-704

Ward BB, Bronk DA (2001) Net nitrogen uptake and DON release in surface waters: importance of trophic interactions implied from size fractionation experiments. Mar Ecol Prog Ser 219:11-24

Weiss RF (1970) The solubility of nitrogen, oxygen, and argon in water and seawater. Deep-Sea Res 29:459-469

Submitted: December 19, 2003; Accepted: September 13, 2004 Proofs received from author(s): October 25, 2004 